\title{
Psychological, pedagogical, and digital aspects of distance learning in Kazakhstan in the context of the COVID-19 pandemic
}

\author{
G.M. Burakanova ${ }^{1 *}, A . G$. Orazgaliyeva ${ }^{2}$, and S.M. Pinaev ${ }^{3}$ \\ ${ }^{1}$ L.N. Gumilyov Eurasian National University, Nur-Sultan, Kazakhstan \\ ${ }^{2}$ L.N. Gumilyov Eurasian National University, Nur-Sultan, Kazakhstan \\ ${ }^{3}$ Peoples' Friendship University of Russia, Moscow, Russian Federation
}

\begin{abstract}
The article provides an assessment by the participants of the educational process (students, teachers, administration) of the transition to distance learning in educational organizations in the context of the COVID19 pandemic, based on a survey conducted in all regions of Kazakhstan. The results of the study showed that the emergency transition of universities to distance learning in connection with the pandemic declared by WHO had a significant impact on the quality and organization of the pedagogical process. This is largely due to the insufficient level of readiness of the relevant state bodies to ensure the material and technical transition to distance learning linked to the previous low rates of digitalization of infrastructure and the ways of interaction between relevant government agencies and educational institutions of the country. Most of the students studied using a smartphone, which signals the lack of a high-quality and efficient educational online platform. The results of the study revealed the need for diversified psychological, pedagogical, and methodological training of teachers in the framework of cyber pedagogy.
\end{abstract}

\section{A problem statement}

The introduction of a state of emergency (hereinafter referred to as SoE) and strict quarantine measures in the country due to the threat of the spread of the coronavirus COVID-19 led to the forced transition of the education system of Kazakhstan to distance learning. Lineministry and state authorities was necessary to determine the form of distance learning students.

According to UNESCO, after the pandemic was declared, 191 countries of the world switched to distance learning. Each country has chosen its own format or combination of formats. Among the main ones: only online learning, a combination of online learning and television or radio broadcasting, television and radio broadcasting, only television, only radio. At the same time, such a pattern was revealed that countries with less developed economies more often used television and / or radio broadcasting, and more developed countries - online learning (exclusively) or in combination with other types of sources [1].

\footnotetext{
* Corresponding author: galiyab@mail.ru
} 
As shown by online test sessions, Internet communication in Kazakhstan could not withstand the load of simultaneous education of 3.3 million schoolchildren and about 1 million students of colleges and higher educational institutions. This state of the online format negatively affects the psychological state of the subjects of the educational process and teaching methods. Before the SoE, some universities used online platforms for distance learning, including Platonus, Moodle, Univer 2.0, Microsoft Teams. For example, according to information posted on the Platonus online platform, among its partners are L.N. Gumilyov Eurasian National University, M. Narikbayev Kazakhstan Humanitarian Law University, Kazakh National Agrarian University, Almaty Management University, Kazakh National Academy of Arts. T.K. Zhurgenova [2-6].

The Ministry of Education and Science of the Republic of Kazakhstan reported that to improve the quality of education, republican online seminars are held daily on various aspects of organizing training using distance educational technologies. All universities and colleges have a HelpDesk system that provides technical support to students and teachers [7].

Most of the nonresident university students returned home and studied at home.

In general, the pandemic of the coronavirus infection COVID-19 has identified a number of issues and posed significant challenges to the country's pedagogical education system at all levels [8].

\subsection{The objective of the work}

Insufficient preparation of the competencies of the teaching staff for conducting online lessons and lectures, poor provision of information and communication technologies, access and high-quality Internet connections, which does not allow organizing a full-fledged online distance education process, as well as a low level of computer literacy of the population and public involvement in educational process, did not allow to continue the educational process without losing the quality and accessibility of education in the context of pandemic [9-13]. The purpose of study is to examine the impact of distance education on the effectiveness of the psychological and pedagogical process of teaching and training the competencies of professional personnel in higher educational institutions of Kazakhstan.

\section{Results of the research}

A mass survey of participants in the field of education was conducted, within the study of "Socio-Economic Impact Assessment (SEIA)", supported by the United Nations Development Program in Kazakhstan (UNDP) and UNICEF. The results of this study are aimed at supporting the government's actions to overcome the crisis caused by the COVID19 pandemic, strengthening the government's capacity to provide various public services, including educational, provided on a distance basis, will serve as a basis for further work to prepare for similar systemic threats in accordance with more effective approaches to the digitalization of the activities of state bodies of Kazakhstan.

In total, 1,334 respondents from among the participants in the education sector took part in the study: 1,157 university and college students from all regions of the country, respondents were selected in proportion to the distribution of students in the context of regions, 44 head of the administration of universities and colleges, and 133 teaching staff of universities and colleges. The survey covered at least one university and college in each of the 17 regions of Kazakhstan.

Half of the surveyed are students of State universities, almost $30 \%$ - study in private, about $11 \%$ - in national, $8 \%$ - in international universities. More than half of the respondents are taught in Kazakh, 31\% - in Russian, about $6 \%$ of respondents trained in three or more languages. $94.4 \%$ of the respondents are undergraduate students, about $4 \%$ are studying for 
a master's program, $1.1 \%$ for a doctorate. Half of the respondents pay for their education themselves, half - study at the expense of the state budget. About $70 \%$ of the respondents were female students, $30 \%$ were male.

Two thirds of the students surveyed belong to the age group 18-20 years old, about 22\% - 21-23 years old. 5\% of students under 18 years old participated in the survey, $5.9 \%-24$ years old and older. In addition, 89 university professors took part in the survey: $62 \%$ of university professors, aged 31 to 49 . Surveyed university professors - $63 \%$ are women, $37 \%$ are men; $42 \%$ of university teachers conduct the learning process in the Kazakh language, another $20 \%$ - in two languages; $28 \%$ of university teachers teach in Russian.

The study showed that almost all the surveyed students have at least a smartphone at their disposal. But every fifth does not have a laptop, every third - a computer at home. About $11 \%$ of the respondents answered that they have neither a computer nor a laptop.

About $10 \%$ of the respondents did not have access to the Internet before quarantine, half of them connected it to be able to study. Every fourth respondent thinks the Internet speed is not high enough to complete online training, another third of the respondents noted that there are periodic failures of Internet connection, but in general this did not interfere with training. About $43 \%$ of respondents are fully satisfied with the Internet speed. Almost all the surveyed students note that they switched to online education: $96 \%$ - in full, $2.5 \%$ - in part. In the vast majority of cases $(91.3 \%)$ a stable schedule of classes was developed for distance learning (most often coinciding with the usual one).

The administration and professors at universities and colleges also report that the transition to distance learning has fully taken place. At the same time, a little more than a third of university professors and about $45 \%$ of university leaders noted that they encountered temporary difficulties when switching to distance learning. Teachers held a difficulty in transition to distance learning more often $(50 \%)$.

Most professors and heads of administration believe that distance learning covers all students. At the same time, the opinions are differed as to how many students were not involved in the distance learning process.

Among the heads of universities and colleges $63 \%$ of the respondents believe that not a single student has "dropped out" from the learning process, and another third believes that the number of such students is minimal. Among university professors, 55\% of the respondents agree that all students are enrolled in training, 32\% expressed the opinion that the minimum part of the students "dropped out" of the learning process. Every tenth professor pointed that a significant part of students was not covered by distance learning. Thus, there is a gap in the perception of the situation during the quarantine. It leads to the fact of misinformation about student attendance.

According to students' answers, the most used gadget for teaching was a cell phone (74.6\%), mostly because almost everyone has it and it does not require a Wi-Fi connection. More than a half $(60 \%)$ of the respondents use a laptop for distance learning, least used gadget is PC.

The question of what online platforms students use for distance learning made it possible to determine that Kazakhstani universities most often use foreign developments. Only a quarter of the respondents study on the Kazakh online educational platform Platonus. Most respondents trained using Zoom (78\%) online video conferencing platform. Other resources, such as Moodle (13.1\%) and Google Classroom (10.5\%), were much less popular.

The choice of online platforms for distance learning suggests that in many universities online learning had a truncated functionality: teachers most often chose the video conference format (Zoom), rather than complex applications for managing the learning process, including distance learning (Platonus, Moodle, Google Classroom, MS Teams). Adepts of the principles of cyberpedagogy note that with this approach (using a computer and the Internet to broadcast traditional classes developed in a standard way), education will carry 
all the disadvantages of traditional education. "By itself, a computer does not change the pedagogical system of education. If traditional teaching is incorporated into it, then the computer will reproduce traditional teaching with $100 \%$ accuracy. If the training program embedded in the computer is built on the principles of cyber pedagogy, the educational process will be reproduced, corresponding to the diagnostically set training goal".

According to the survey of the heads and professors at the universities and colleges Zoom is the most popular distance learning program (cited by vast majority of the respondents). Also, every second respondent names the Kazakh platform for distance learning Platonus, Skype, YouTube channels, and Google Classroom as a key platform for teaching students.

The interviewed university students note that they most often received mailings and homework from the teacher through the educational platform used by the university $(63 \%)$ or via WhatsApp (61\%). About $40 \%$ of the respondents received a newsletter from a professor by e-mail.

Despite the lack of strict control, most of the respondents note that the learning process has not changed for them, they continue to attend all classes and complete all tasks (79.2\%). $14.5 \%$ of respondents skipped classes rarely and for a good reason. Slightly more responsible were students who study on a budgetary basis and receive a scholarship, who more often noted that they did not miss classes or did not miss them only for a good reason. There are certain gender differences: among girls, $81 \%$ of respondents did not miss classes, among boys - about $75 \%$.

The respondents most often spent $2-4$ hours $(37 \%)$ or even half a day $(30 \%)$ on preparing their homework. Freshmen and scholarship recipients spent the most time preparing their homework. Girls more often noted that they spend most of the day or all day on homework $(15 \%$, among boys $-10 \%)$.

The main source of information in preparation for seminars and student independent work (IWS) was the Google search engine - $62 \%$ of students call it a key source.

Only about $18 \%$ of students note that they use the online library of the university, about $15 \%$ - the online portal of the university with educational and methodological materials located on it.

Assessment of the effectiveness of the organization of the learning process showed the following. About $19 \%$ of respondents believe that the transition to distance learning did not affect the quality of the education they receive. This was the most frequently answered by respondents studying on a state educational grant (22.4\%) and receiving a scholarship (22\%). Given that these are the groups who spend the most time preparing and skipping online classes the least, it can be assumed that the productivity and quality of education largely depends on the efforts of the students themselves.

About $42 \%$ of university students believe that distance learning makes their education a quarter less productive, and $28 \%$ of respondents rate the productivity of online learning even lower - only $50 \%$ of the possible.

In general, most teachers and leaders of educational institutions admit that during distance learning, the opportunities for testing students' knowledge are lower than during face-to-face training. Among university professors, only $28 \%$ of respondents believe that the quality of knowledge testing has not changed. At the same time, about $10 \%$ of university professors believe that the distance learning methodology of the subject is developed "rather poor" or "poor".

According to the majority of the surveyed students, the university provided them with the necessary organizational and technical conditions for online learning: $61 \%$ of respondents fully adhere to this opinion, $12 \%$ rather agree with it. At the same time, every fourth respondent believes that their university did not provide them with all the necessary conditions. Students who study on a paid basis were more critical ( $28 \%$ of negative answers). $90 \%$ of the surveyed university students are satisfied with the work of educational online 
services, technical support of the university in the framework of distance learning. $96 \%$ of respondents rate highly informing about the learning process online.

More than half (69\%) of respondents have access to the university's online library, but only $18 \%$ of students use it to prepare for classes, which can be regarded as an indirect assessment of the quality and range of materials available there. About $17 \%$ of university students use the services of third-party online libraries (regional, city, online libraries of other universities, etc.). Every fourth student is not aware of the availability of online libraries in principle. This is most often answered by students studying on a paid basis $(29.5 \%)$, Russianspeaking (29.9\%), students of private universities (31.3\%).

All interviewed heads of universities are sure that their university has an Internet resource with all educational materials for self-study of students. The fact that not all students are aware of the availability of such an Internet resource may indicate poor-quality work to inform students. Another option is that the heads of universities are not sufficiently close to the realities of the learning process or are trying to show their educational institutions from the best side. Among university professors, only $42 \%$ are aware of the availability of a resource with teaching materials on their subject.

The experience gained during the forced transition to distance learning in higher education shows that not all higher education organizations are ready for a full transition to distance learning. The opinions of university students were almost equally divided: $49.7 \%$ of respondents believe that the higher education system is rather or unequivocally not ready for the transition to online education; $43.1 \%$ - adhere to the opposite point of view.

However, at the same time, the share of those who unequivocally negatively assess the potential of the higher education system to switch completely to distance learning forms $(33.7 \%)$ is $10 \%$ more than those who assess this potential unequivocally positively $(23.5 \%)$. This indicates rather serious doubts and certain problems in the organization of distance learning.

Every second university student during distance learning faced the problem of low Internet speed. Almost a third of the respondents had limited access to the Internet, Internet connections were interrupted, or they had to make additional efforts to access the Internet (go to a high place, etc.). Slightly more than $20 \%$ of respondents consider an increase in the volume of independent work to be a disadvantage of distance learning. $17 \%$ of university students are dissatisfied with the inconvenient functionality of the educational platform. It is noteworthy that students using the Moodle app say this more often than others $(25 \%)$. About $7 \%$ of respondents noted remote work with a teacher as a problem: difficulties in communication online (7.3\%) and the teacher's unwillingness to work online $(7.3 \%)$. Every fourth university student surveyed noted that they had no problems during distance learning.

Most of the heads of universities (78\%) believe that there were no difficulties in the transition to the distance learning format at their university. Those who named any difficulties most often referred to the lack of technical capabilities among students at home $(11.1 \%)$. Teachers, less often than managers, noted that they did not encounter difficulties when switching to distance learning.

Perception of the consequences of switching to distance learning, respondents named both positive and negative aspects. On the one hand, online learning made it possible to independently organize study time (52.4\%), significantly diversified the forms of education, and began to use the opportunities of online conferences, webinars, and online courses (41.5\%). In addition, the students surveyed express their hopes that such distance learning experience will accelerate the digitalization of higher education $(32.2 \%)$ and improve the quality of education. About $5 \%$ of respondents note that they have free time. $15 \%$ of the university students surveyed do not see any positive consequences of the transition to online education. 
Among the negative consequences, the respondents named a decrease in the availability of educational materials (the absence of online libraries, for example), as well as limited opportunities to get advice from a teacher (33.6\%). Along with this, $31 \%$ of students note a decrease in the quality of education and teaching due to the consequences of the transition to a distance format. $20.6 \%$ of respondents also note a decrease in control over the implementation of tasks. At the same time, every third survey participant believes that there are no negative consequences of the transition to the remote format.

The main wish of the surveyed students in overcoming the negative effects of the transition to a distance format was to solve the problems with the availability and speed of the Internet connection - this option was named by $12 \%$ of respondents, and $7 \%$ of university students would like to return to traditional forms of education.

The majority (78\%) of university leaders are convinced that their organizations are ready to provide continuous high-quality distance learning in the future. Among the teachers, only about $50 \%$ are unambiguously ready. Teachers show almost unanimous willingness to participate in additional training on organizing distance learning - $92 \%$ of university teachers.

Heads of universities perceived the experience of distance learning so positively that almost $90 \%$ of them plan to continue developing in this direction. The question naturally arises of how the cost of distance learning services should change. On the one hand, students may believe that distance learning should cost less, since productivity is lost, and the material and technical component is not involved (building, equipment, furniture, etc. do not wear out). So, for example, the All-Russian Student Union made a petition to reduce the cost of education during quarantine [14-18]. In the United States, there are discussions that online learning can be a way to reduce the cost of education, which now is becoming unaffordable for many students, and for those who have already studied, it remains a burden for many years after training [19]. But in Kazakhstan, distance learning programs that were in effect before the quarantine differed little in cost from the classical ones [20]. Perhaps the fact is that most of them continue to demand the personal inclusion of teachers, and this affects the salary fund. For some universities, the transition to distance learning may require significant investments in logistics, payment of subscription fees for using services of Internet platforms, training of teachers, filming videos, salaries of curators or distance learning coordinators. There is a risk that this can become a financial burden for students who study on a paid basis.

The opinions of all four groups of respondents differed as to what measures the Ministry of Education and Science of the Republic of Kazakhstan should take to ensure high quality of distance learning. Heads of universities consider the most priority issue to ensure uninterrupted Internet connection (85\%), to provide free access to electronic resources of distance education (78\%), to organize training of personnel in distance learning skills $(70 \%)$. University professors believe that, first, it is necessary to ensure a constant exchange of experience in organizing distance learning (55\%).

\section{Conclusions}

Only $19 \%$ of university students believe that the transition to distance learning did not affect the quality of education in any way. According to $70 \%$ of respondents, the productivity of education has decreased by at least a quarter.

The preference by students of recognized search engines for the online library of the university may be due to the insufficient fund of digitized literature, the difficulty of using the library, the inconvenient format of materials (scanned versions of paper books), and insufficient awareness of students about the possibilities of using the online library.

Teachers and the administration of educational organizations most often note the lack of technical conditions among students. However, according to a survey among students, only $11 \%$ have no computer or laptop. At the same time, most of the students studied using a 
smartphone, which signals the absence of any high-quality and efficiently working educational Internet platform.

Representatives of the administration of universities positively assess the transition to distance learning and view it as an additional opportunity for the development of the education system.

Thus, the decrease in the quality and productivity of education noted by both students and teachers during the transition to distance learning (in a pandemic) is largely due to an insufficient level of readiness of related state bodies to ensure the material and technical, infrastructural transition to distance learning due to the previous low rates of digitalization in the country, ineffective approaches of interaction between state bodies and educational institutions, as well as the need for diversified psychological, pedagogical and methodological training of teachers in the framework of cyber pedagogy. Teachers transferred traditional teaching methods to an online format, found it difficult to provide feedback with students, and difficulties in monitoring the progress in digital mode. There was a significant psychological overload during the forced mastering of online technologies by teachers. The results obtained suggest the presence of delayed consequences of restricting access and reducing the quality of educational services for students, which should be considered when formulating measures to control the knowledge gained by students and additional psychological and pedagogical training of teachers in the post-quarantine period.

\section{References}

1. V. Emiliana, School closures, government responses, and learning inequality around the world during COVID-19, [Electronic resource]: https://www.brookings.edu/research/school-closures-government-responses-andlearning-inequality-around-the-world-during-covid19/?fbclid=IwAR0cTKwOYtJlx5VMphfpqQNVnxCRr9uXzoRcD8g7TrjgkU4xn7O0enUp-o (2020)

2. E.V. Chernobay, D.N. Tashibaeva, Professional development of teachers in the Russian Federation and the Republic of Kazakhstan on the results of the TALIS-2018 research, [Electronic resource]: https://cyberleninka.ru/article/n/professionalnoe-razvitieuchiteley-v-rossiyskoy-federatsii-i-respublike-kazahstan-po-rezultatam-issledovaniyatalis-2018 (2020)

3. M. Fitzpatrick, D.T. Figueroa, G. Golden, S. Crosby, Education Policy Outlook, [Electronic resource]: https://eric.ed.gov/?id=ED592576 (2018)

4. S. Thomson, K.J. Hillman, TALIS 2018: the Teaching and Learning International Survey Results, Teachers and School Leaders as Lifelong Learners, I (2018)

5. J. Fraillon, J. Ainley, W. Schulz, D. Duckworth, T. Friedman, IEA International Computer and Information Literacy Study 2018 Assessment Framework, [Electronic resource]: https://www.springer.com/gp/book/9783030193881 (2018)

6. Zh. Nurbaev, Why Did Kazakhstan Fail The International PISA Assessment, [Electronic resource]: $\quad$ https://cabar.asia/en/why-did-kazakhstan-fail-the-international-pisaassessment (2020)

7. The results of an international study on the assessment of the quality of reading and text comprehension of 4th grade students PIRLS-2016, International Association for the Evaluation of Educational Achievements IEA, [Electronic resource]: http://iac.kz/ru/project/pirls (2017)

8. T.B. Cherepanova, Trends and tendencies of modern educational practice, Bulletin of the Omsk State Pedagogical University. Humanities research, 2(23), 139-141 (2019) 
9. E. Armstrong-Mensah, K. Ramsay-White, B. Yankey, Sh. Self-Brown, COVID-19 and Distance Learning: Effects on Georgia State University School of Public Health Students, Public Health, [Electronic resource]: https://www.frontiersin.org/articles/10.3389/fpubh.2020.576227/full (2020)

10. P.A. Fidalgo, J. Thormann, O. Kulyk, J. Alberto Lencastre, Students' perceptions on distance education: A multinational study, International Journal of Educational Technology in Higher Education, 3 (2020)

11. M. Simonson, Distance learning, [Electronic resource]: https://www.britannica.com/topic/distance-learning (2020)

12. The COVID-19 pandemic has changed education forever, World Economic Forum, [Electronic resource]: https://www.weforum.org/agenda/2020/04/coronaviruseducation-global-covid19-online-digital-learning/ (2020)

13. S. Carr, As Distance Education Comes of Age, the Challenge is keeping the Students, The Chronicle of Higher Education, [Electronic resource]: https://www.chronicle.com/ (2020)

14. V.L. Shatunovskiy, E.A. Shatunovskaya, Once again about distance learning (organization and provision of distance learning), Bulletin of Science and Education, 9(87), 53-56 (2020)

15. D.V. Novoselova, D.V. Novoselov, Distance learning in a pandemic, Theory and practice of scientific research: psychology, pedagogy, economics and management, 3(11), 35-38 (2020)

16. D.A. Smogorzhevsky, The main problems of distance learning, StudNet, 12, 347-358 (2020)

17. S.V. Matvienko, E.V. Vasilyeva, N.Yu. Polyakova, V.V. Evdokienko, Psychological difficulties arising in the process of distance learning and ways to overcome them, Education and Law, 4, 195-199 (2021)

18. Y.A. Kulagina, I.M. Morozova, Organization of independent work in the conditions of distance learning, International Research Journal, 01(103), 136-139 (2021)

19. S. Naidu, Building resilience in education system post-COVID-19, Distance Education, 42(1) (2021)

20. N. Nurmukhametov et al., The Problems of Development of Distance Education in Kazakhstan, Procedia - Social and Behavioral Sciences, 182, 15-19 (2015) 